\title{
Ecological Implications of Changes in the Arctic Cryosphere
}

\author{
Warwick F. Vincent, Terry V. Callaghan, Dorthe Dahl-Jensen, \\ Margareta Johansson, Kit M. Kovacs, Christine Michel, \\ Terry Prowse, James D. Reist, Martin Sharp
}

\begin{abstract}
Snow, water, ice, and permafrost are showing evidence of substantial change in the Arctic, with large variations among different geographical areas. As a result of these changes, some habitats and their associated ecosystems are expanding, while others are undergoing rapid contraction. The warming of the Arctic cryosphere is limiting the range for cold-adapted biota, and less specialized taxa including invasive species from the south are likely to become increasingly common. Extreme climate events such as winter thawing are likely to become more frequent, and may accelerate shifts in community structure and processes. Many Arctic ecosystems are interdependent, and changes in the cryosphere are altering physical, biogeochemical, and biological linkages, as well as causing positive feedback effects on atmospheric warming. All of these climate-related effects are compounded by rapid socio-economic development in the North, creating additional challenges for northern communities and indigenous lifestyles that depend on Arctic ecosystem services.
\end{abstract}

Keywords Arctic Ocean - Biodiversity - Climate change · Cryosphere $\cdot$ Polar ecosystems

\section{INTRODUCTION}

The Arctic region contains a remarkable diversity of habitats and associated ecosystems, from mountain glaciers and ice caps to tundra, inland waters, and icy seas. Many of the ecosystems are interdependent, and changes in climate (Walsh et al. 2011a, b [this issue]) are beginning to have not only direct effects on the ecology of these environments, but also indirect effects through the physical, biogeochemical, and biological coupling between them (Fig. 1). These impacts will have direct consequences for people living in the North via changes in ecosystem services, and indirect consequences elsewhere, for example via changes in global biodiversity, biogeography, and biogeochemical fluxes. The shifts in Arctic ecosystem structure and dynamics are also resulting in a variety of feedback effects that may accelerate their rate of change (Callaghan et al. 2011a, b [this issue]). This article provides an overview of how climate-dependent alterations in snow, water, ice, and permafrost are affecting, and will increasingly affect, the ecology of the Arctic including potential impacts via the linkages between ecosystems. This summary is based on results from the "Snow, Water, Ice, Permafrost in the Arctic" (SWIPA) project conducted by the Arctic Monitoring and Assessment Program, and is condensed from the ecology synthesis chapter of the SWIPA report (Vincent et al. 2011).

\section{SNOW}

Over the past 40-50 years there has been an overall trend of increasing winter precipitation in the Arctic (Callaghan et al. 2011c, d [this issue]) concomitant with warming air temperatures (Walsh et al. 2011a, b [this issue]). However, there is large spatial variability in current and projected future trends (Brown and Mote 2009), and thus ecological responses can also be expected to vary among regions. There is a consistent projected trend of decreased snow cover duration (SCD) throughout the Arctic, with the greatest changes predicted to occur in the most southerly regions (Brown and Mote 2009). The ecological effects of these pronounced changes may be compounded by a shift toward increasingly frequent episodes of winter rain and melting that cause surface ice crusts over the snowpack, although basal ice layers that also impede animal foraging 


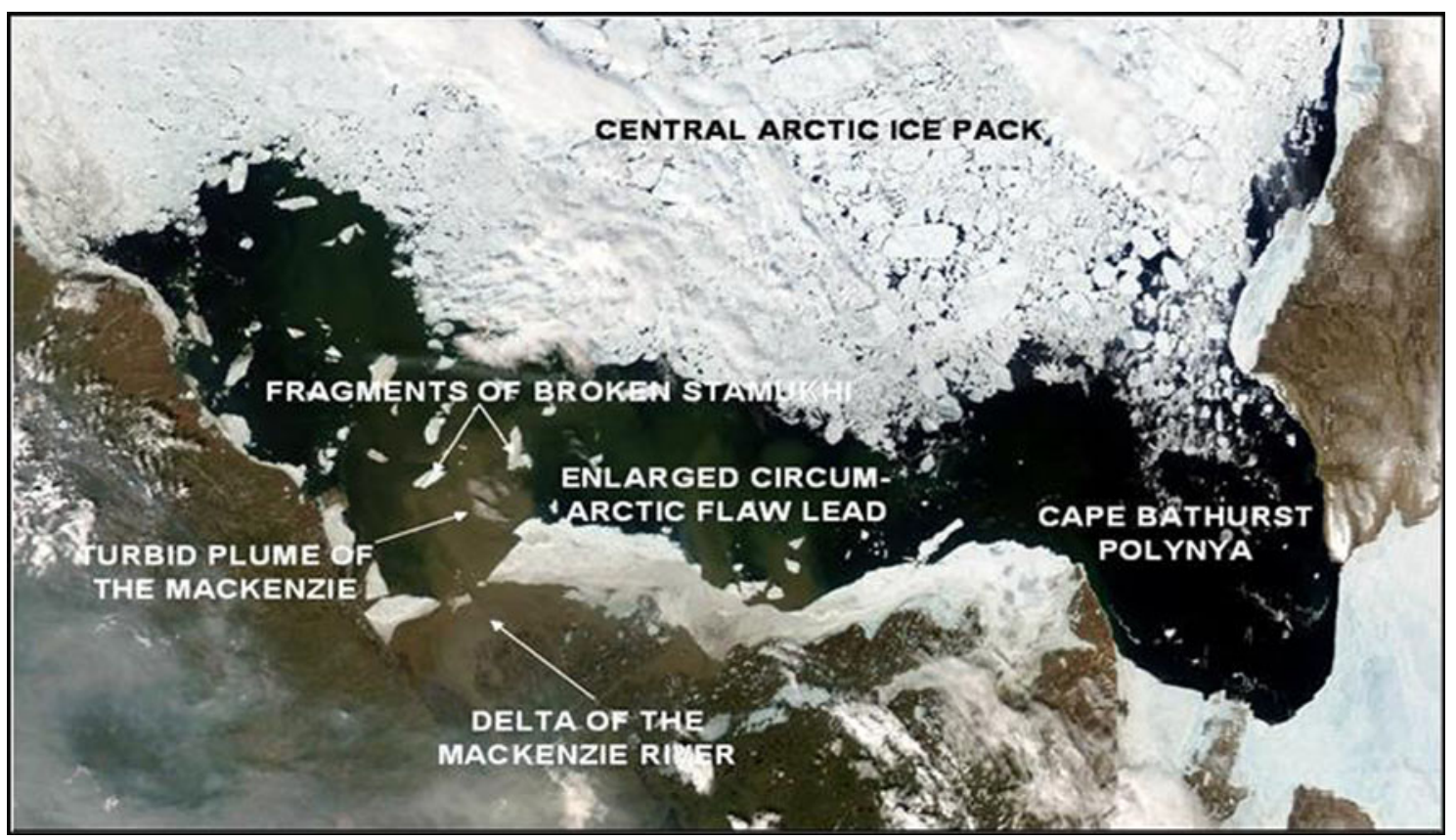

Fig. 1 Changing ice conditions in the Arctic and effects on ecosystem coupling. In the Mackenzie River, decreasing ice jams are resulting in less flooding of higher elevation lakes and wetlands (Lesack and Marsh 2007). Changes in the stamukhi ice barrier along

may become less frequent given the progressively shorter duration of snow cover.

In the terrestrial environment, changes in snow cover have wide-ranging ecological effects on soil, plant, and animal communities, as well as affecting lakes, rivers, and wetlands. Snow is a habitat for diverse microbial communities including snow algae and associated bacteria and fungi. These organisms provide organic carbon and nutrients to the soil during snow melt. Snow also acts as an insulator for Arctic soils, and increased snow depth (predicted for the high Arctic) may result in warmer winter soil temperatures, increased biogeochemical processing of organic materials, and increased respiration (details in Vincent et al. 2011).

Many Arctic plants, especially lichens and bryophytes, become physiologically active even before the overlying snow completely melts. However, this competitive advantage may be lost with the earlier disappearance of snow, and the longer, warmer growing season may favor the invasion of plants from more southern latitudes. Extreme warming events in winter can result in the sudden loss of protective snow over vegetation and cause a variety of damage including mortality of buds and shoots, delayed bud burst in spring, and reduced flowering, decreased rates of primary production and the loss of winter dormancy, which renders the plants vulnerable to subsequent freezing (details in Callaghan et al. 2011c).

Snow quantity and quality have strong effects on the ecology of Arctic animals (Figs. 2, 3). For migratory the coast may alter the biogeochemical processing of the river water discharged to the Arctic Ocean (Galand et al. 2008). Photocredit: MODIS image, June 2004, reproduced from Fortier et al. (2008) by permission of Aboriginal Press

species, small changes in the end date of snow cover can translate into large changes in breeding success (e.g., pinkfooted geese, Madsen et al. 2007). The duration of snow cover directly affects the subsequent duration of the growing season for plants and therefore the food resources available to Arctic herbivores (e.g., reindeer in Finland, Turunen et al. 2009; musk ox in Greenland, Forchhammer et al. 2008). On Ellesmere Island, Canada, years of extensive snow cover in the past have resulted in reduced vegetation growth and reduced herbivore populations (musk ox and Arctic hare), which in turn resulted in reduced populations of Arctic wolves that prey on the herbivores (Mech 2004). The formation of surface and basal ice-crusts can drastically reduce the availability of the underlying vegetation to herbivores (see below). The overall hardness of the snowpack can also affect the availability of subnivean spaces for lemmings, and the resultant changes in their populations can have indirect effects on other species used as alternate prey by their shared predators (Kausrud et al. 2008).

\section{WATER}

Water availability rather than temperature appears to be an increasingly limiting factor for the northward progression of the treeline, with previous trends of positive tree growth now appearing to be weaker, non-existent, or even reversed 
Fig. 2 Changing snow conditions affect vegetation and wildlife. Increased winter snow cover has a direct negative effect on resident species such as musk ox, and the duration of snow-free conditions in summer has an indirect positive effect on herbivores by allowing a longer season of plant growth (details in Callaghan 2011b).

Photocredit: Miroslav Chum/ ArcticNet
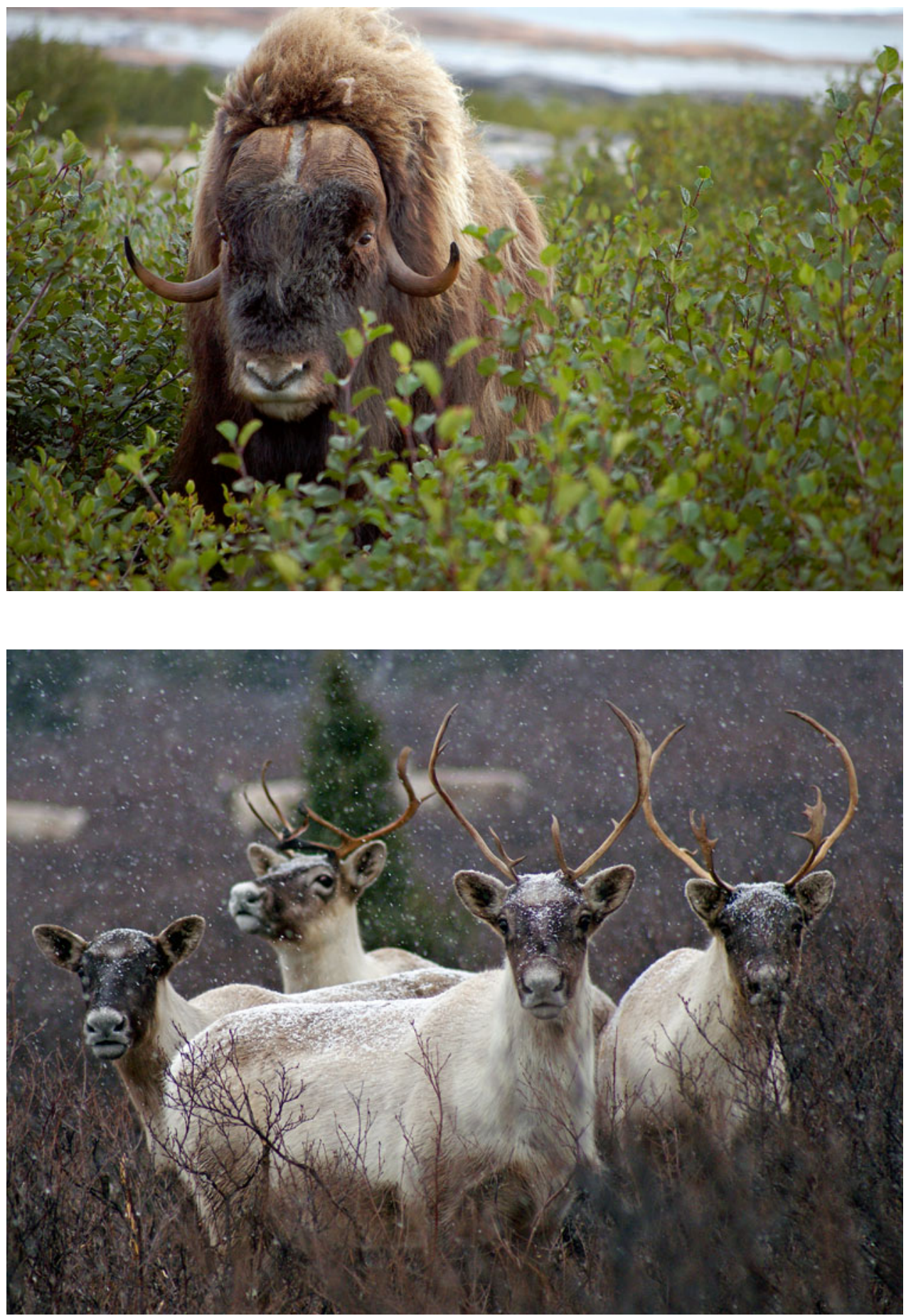

Fig. 3 Caribou populations are in decline throughout much of the circumpolar Arctic. For the northernmost herds, this has been attributed in part to changing snow conditions (Vors and Boyce 2009). These large reductions in population size are likely to alter the vegetation ecology of northern ecosystems, as well as impact traditional hunting. Photo credit: Joëlle Taillon/Caribou Ungava, CEN and ArcticNet

as a result of temperature-induced drought (Wilmking et al. 2005). These observations imply that the treeline will advance over the course of this century in a non-uniform way, colonizing those parts of the landscape where there is sufficient moisture.

Many Arctic aquatic ecosystems have begun to show shifts in water balance, in some cases leading to the complete drying-up of lakes and wetlands (e.g., Smol and
Douglas 2007). As late-lying snow banks are an important source of water for wetlands (Woo and Young 2003), semiaquatic ecosystems are therefore also vulnerable to the ongoing trend of decreased snow cover duration, and desiccation of wetlands has been observed at a number of Arctic sites (e.g., Vincent et al. 2009). Thaw-induced erosion also plays a role in the extent of standing waters. The degradation of permafrost soils in Siberia has resulted 
in collapse, drainage, and complete disappearance of many water bodies (Smith et al. 2005), while elsewhere in the Arctic, permafrost thawing over the past 50 years has created new basins and increased development of shallow water ecosystems (Fig. 4).

Warmer Arctic temperatures will be accompanied by a shift in precipitation from snow to rain, with many ecological consequences. For example, rain tends to favor broadleaf over conifer tree species, which in turn may decrease carbon storage, increase soil respiration, and reduce the timber potential of the forest. Sudden rains during winter can result in a rapid loss of protective snow cover that makes the vegetation more vulnerable to freezing damage. Rainfall over snow cover can also result in the production of ice crusts that prevent herbivores from accessing the underlying vegetation (e.g., Rennert et al. 2009). Major declines in Peary caribou in the Canadian Arctic Archipelago have also been attributed to unfavorable snow or ice conditions (Miller and Barry 2009). For marine and freshwater ecosystems, snow affects the penetration of light for photosynthesis in the planktonic communities within and beneath the ice (Vincent and Belzile
2003). Rainwater saturation of snow will greatly increase under-ice irradiance, as well as hasten melting of the remaining snow and ice.

Arctic freshwater systems provide important migratory routes for fish, and changes in climate may alter the connectivity among lakes and river channels, as well as the physical coupling to the coastal marine ecosystem. Glacierfed rivers are showing sustained periods of higher discharge associated with the increased duration and intensity of melt under a warmer climate, and this provides more favorable habitats for some invertebrate and fish species. Increasing discharge has also been observed in the large Siberian rivers, with record flows in 2007 (Shiklomanov and Lammers 2009). This may result in increased nutrient and allochthonous (external) organic matter inputs to the Arctic Ocean that stimulate processes at the base of the marine food web. However, this fresh water combined with the large-scale melting of sea ice is reducing the salinity of the Arctic Ocean mixed layer, thereby intensifying stratification. In recent years, freshening of the Arctic Ocean surface waters has been accompanied by a shift in phytoplankton toward small-celled species that are more

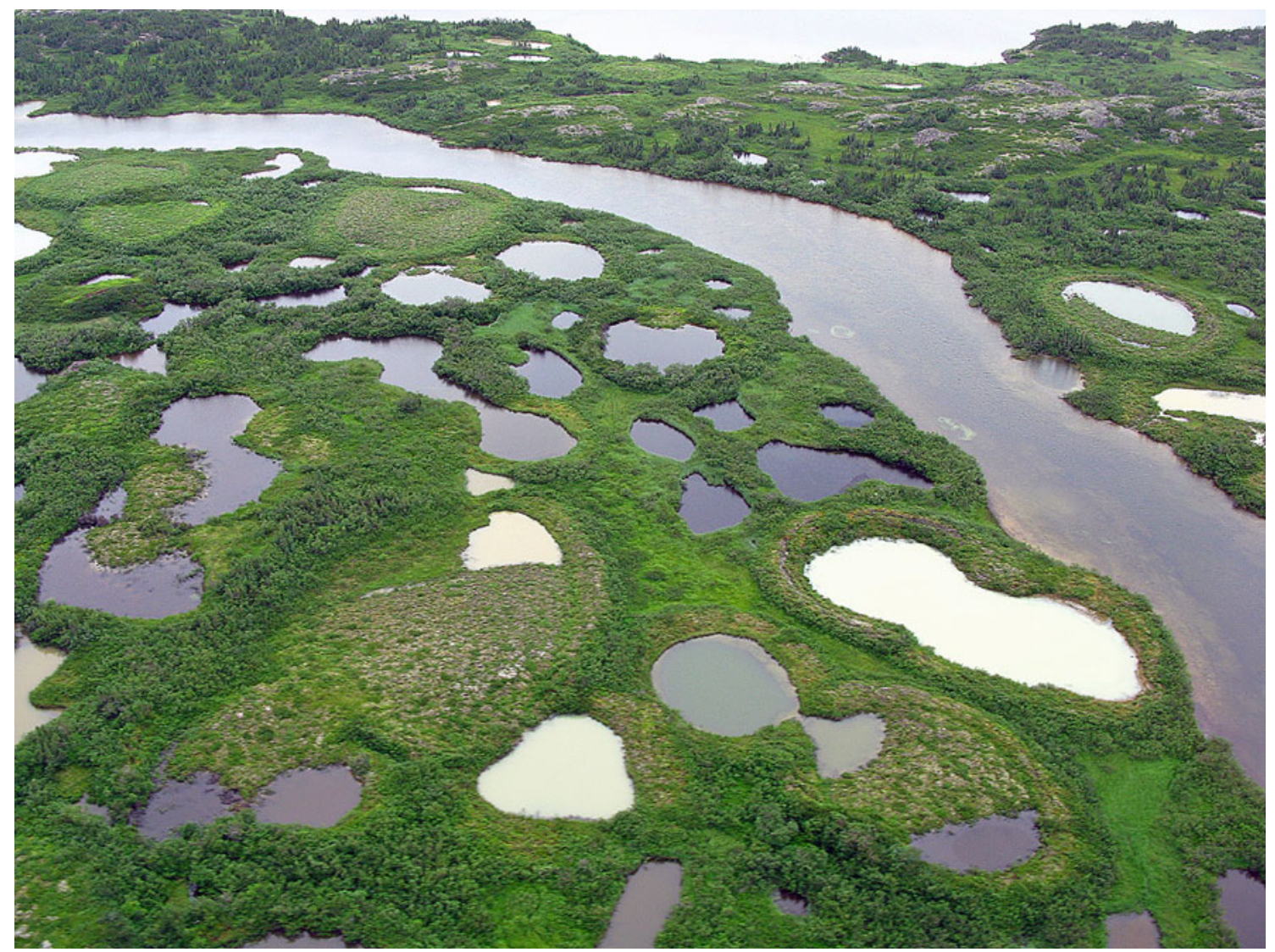

Fig. 4 Permafrost landscapes in transition. Thaw lakes and ponds are eroding and draining in some Arctic regions, while in other areas such as in here in Nunavik, Canada, they are expanding (Callaghan et al. 2011e; and references therein). These biogeochemically active waters convert tundra soil carbon to greenhouse gases. Photocredit: Warwick F. Vincent/CEN and ArcticNet 
competitive in stratified, nutrient-poor conditions, but that are less available for food web transfers to fish communities and benthic ecosystems ( $\mathrm{Li}$ et al. 2009).

\section{ICE}

\section{Greenland Ice Sheet}

The Greenland Ice Sheet has long been recognized as a habitat for microbial ecosystems associated with sediment accumulation and ephemeral meltpools (Vincent 2000 and references therein), and these may become more widespread over the ice as the Arctic climate warms. Runoff from the melting ice cap provides substantial water, nutrients and probably organic carbon to coastal environments around Greenland (Dahl-Jensen et al. 2011), and increased fluxes may affect marine food webs. Changes in iceberg fluxes from the ends of ocean-terminating glaciers may influence benthic communities through ice scouring, and cause local changes in the surrounding environment. The effects of increased melting of the Greenland Ice Sheet on the adjacent marine ecosystems has received little attention to date, but should be an important priority for future research.

\section{Glaciers and Ice Shelves}

Arctic glaciers provide a habitat for cryoconite microbial communities, as well as water supplies for streams, rivers, wetlands, and the coastal ocean (Sharp et al. 2011). From the 1990s onward, there have been increasing rates of mass loss from glaciers in Alaska, the Canadian Arctic, and Iceland, and this trend is likely to continue over the next few decades. In the medium-term, ongoing increases in discharge may stimulate benthic invertebrate diversity (e.g., Milner et al. 2008) and enhance salmonid populations (e.g., Fleming 2005). In the longer-term, the glacial recession (Fig. 5) will open up new terrestrial habitats for colonization by microbes and plants (e.g., Breen and Lévesque 2006), and culminate in declining river discharges and changing stream patterns (Milner et al. 2008). Higher temperatures are likely in the absence of glacial meltwater inputs, which are likely to favor declines among

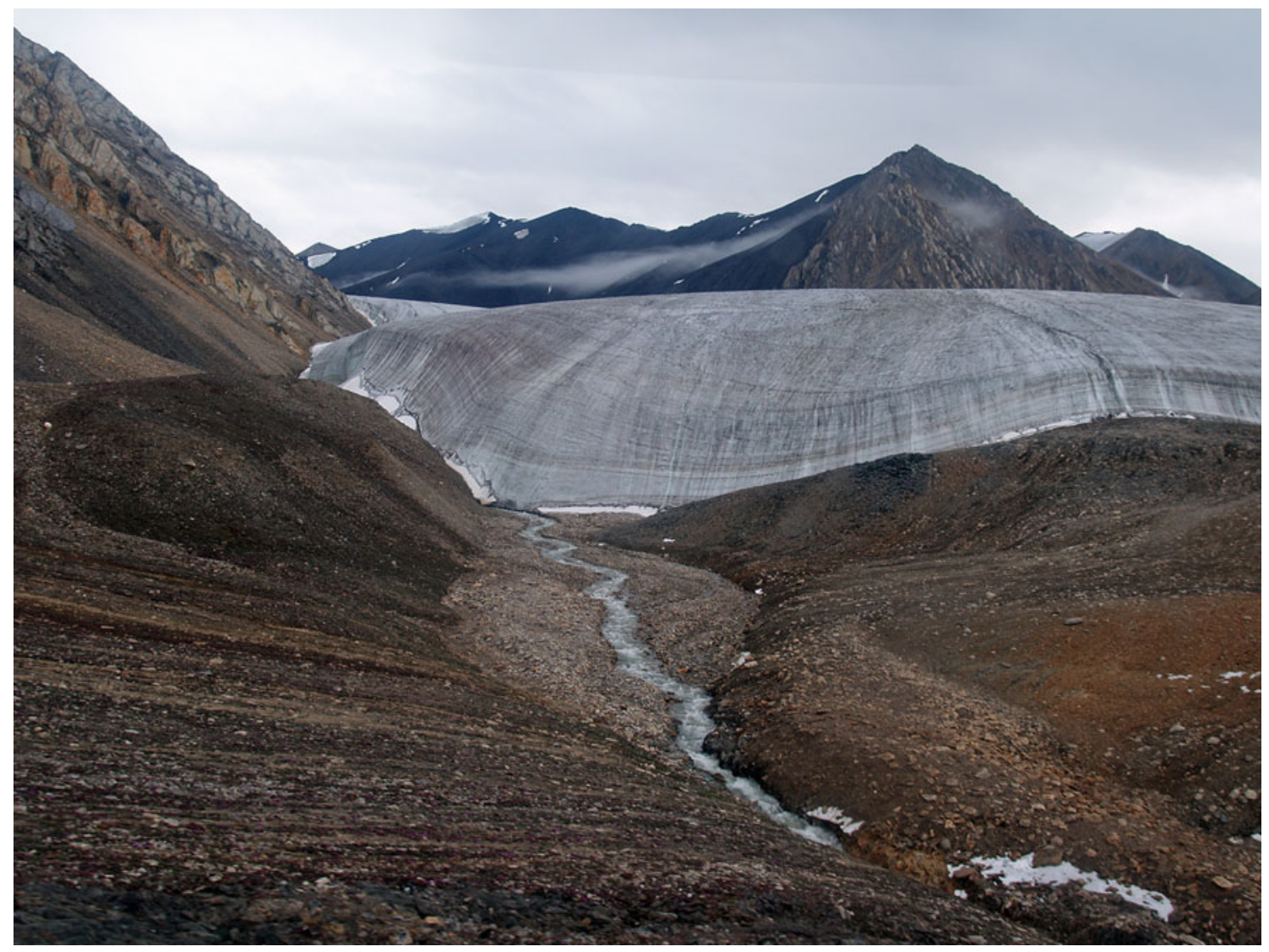

Fig. 5 Glacial retreat and new terrestrial ecosystems. The melting of glaciers throughout the Arctic (Sharp et al. 2011) is causing large fluctuations in river discharge, and is exposing new land for colonization by terrestrial biota. Photocredit: Warwick F. Vincent/ CEN and ArcticNet 
cold-water salmonids and the invasion of warm-water taxa from the south. Changes in runoff volume will also influence the coastal environment, with potential effects on currents, nutrient supply, marine productivity, and fisheries. The eventual retreat of tidewater glaciers will result in loss of the productive glacier-front habitat for marine birds and mammals (details in Sharp et al. 2011).

Unusual ice features in the Arctic and their associated microbial ecosystems are likely to become extinct through ongoing climate change (Vincent 2010). The ancient ice shelves along the northern coastline of Ellesmere Island in High Arctic Canada harbor diverse communities of microbes and micro-invertebrates, and these shelves are currently experiencing rapid attrition (Fig. 6). The ice shelves act as dams at the seaward end of bays and fiords, and they impound incoming freshwater from snow and glaciers to create "epishelf lakes," an ecosystem type that is well known in Antarctica. Fracturing and breakup of ice shelves can cause a draining of such lake ecosystems, and the loss of their unusual fresh and brackish water communities. Only one epishelf ecosystem is believed to remain in the High Arctic (Milne Fjord, northern Ellesmere Island, Canada), and it is vulnerable to ongoing warming (Veillette et al. 2008). The loss of ice shelf ecosystems will affect biogeochemical processing of material entering the sea from land-based ecosystems, and conversely, the newly opened coastal waters are likely to cause accelerated warming of the adjacent terrestrial environment.

\section{Lake and River Ice}

Ice covers Arctic lakes for 6-12 months each year and therefore has a major influence on the physical, chemical, and biological characteristics of these ecosystems. There is evidence of earlier breakup and delayed freeze-up at many sites, and this trend is predicted to accelerate in the future (Prowse et al. 2009, 2011a, b [this issue]). Paleolimnological studies suggest that the shorter duration of snow and ice cover results in higher primary production at sites throughout the Arctic (Hodgson and Smol 2008, and references therein), associated with more light availability for photosynthesis, increased wind-induced mixing, and increased nutrient inputs from catchments in a warmer climate. The longer ice-free period may drive some lakes from cold monomixis (one period of mixing a year) to dimixis (two periods of mixing a year) systems, potentially resulting in warmer waters, shifts in zooplankton communities, and increased contaminant transfer to high trophic levels (details in Vincent et al. 2011). These warmer conditions may force cold-adapted specialists into more

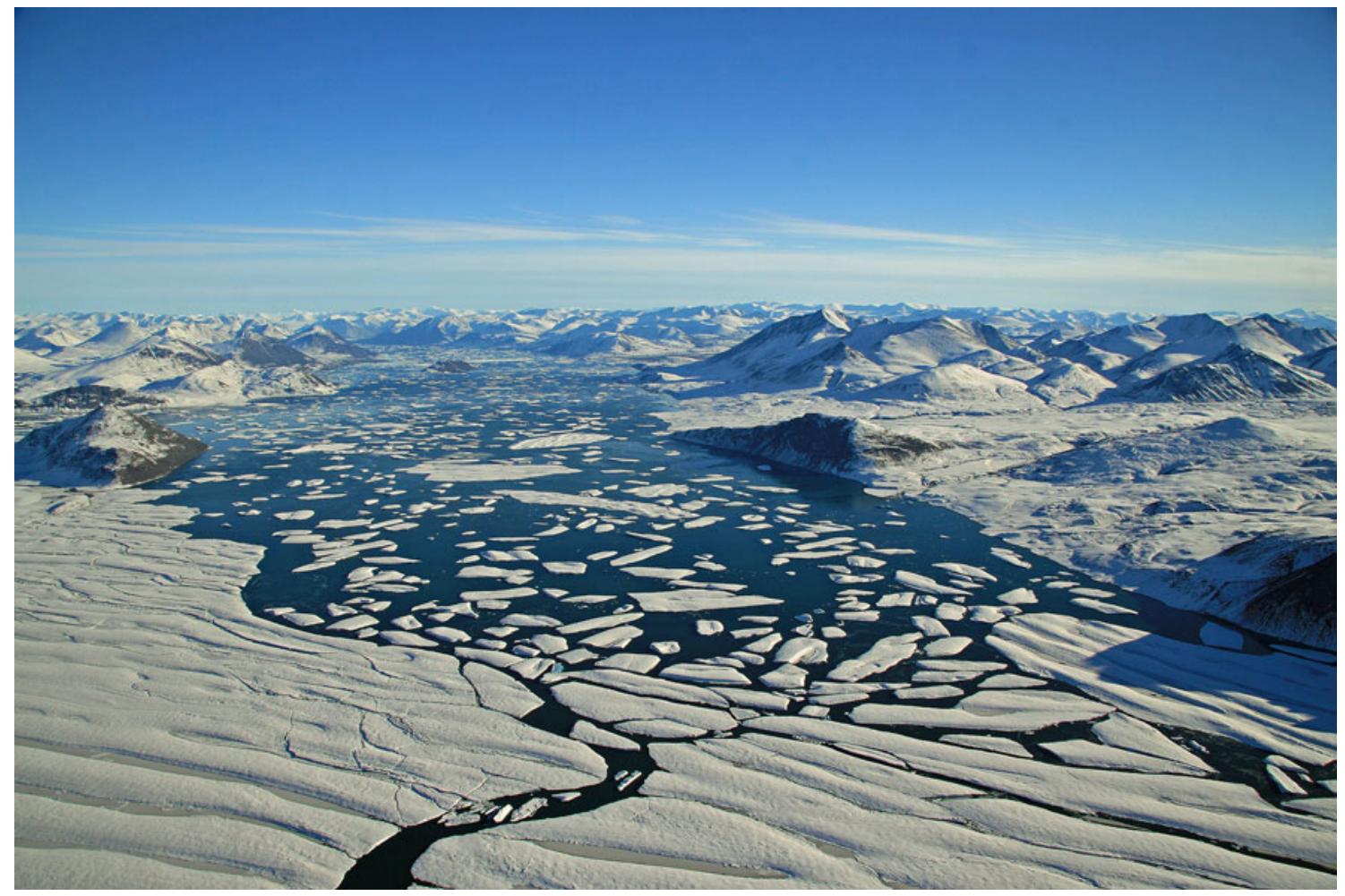

Fig. 6 Extinction of ice shelf ecosystems. Accelerated breakup of ice shelves along the northern coast of Nunavut, Canada, is resulting in the loss of unique microbial ecosystems such as the Ward Hunt Ice
Shelf and its associated ice-dammed freshwater lake in Disraeli Fiord (Vincent 2010). These are being replaced by new open-water marine ecosystems. Photocredit: Denis Sarrazin/CEN and ArcticNet 
restricted habitats, for example Arctic char may be increasingly confined to deep lake habitats (Power et al. 2008).

Changing lake ice will also alter the coupling between these ecosystems and other environments and biota. These climate-dependent changes may influence the through-flow of contaminants from catchments via lakes to the sea (e.g., Semkin et al. 2005). The effect of declining lake ice on increased contaminant exposure is supported by observations on mercury and polychlorinated biphenyl incorporation into burbot, a locally harvested freshwater fish species present throughout many Arctic lakes and rivers (Carrie et al. 2010). The increasing open water conditions may attract aquatic bird populations and thereby new trophic levels (e.g., Vincent et al. 2009), and may favor the competitive success of less cold-tolerant plant, fish, and other organisms invading from the south, perhaps driving some northern species to extinction (e.g., Sharma et al. 2007).

Ice is a major structuring feature of Arctic rivers and their associated flood plain ecosystems, and changes in the duration and magnitude of ice accumulation will have many ecological impacts, not only on these waters but also on the coastal ocean ecosystems into which they discharge (details in Prowse et al. 2011a). Ice reduces winter survival of many river-dwelling organisms (e.g., Huusko et al. 2007), and release from this constraint will have a mixture of negative and positive effects on riverine communities. Reductions in ice cover may result in decreased habitat availability for some fish species; mid-winter breakup may be especially deleterious. Conversely, with ongoing warming, many Arctic rivers that currently have bed-fast ice may open up as winter habitats for fish, and increasing zones of broken ice or open water during winter will enhance the oxygenation of rivers. River ice, especially during breakup, causes substantial bank and channel erosion that not only controls the geomorphology of the fluvial environment and therefore the spatial distribution of habitat types (Prowse et al. 2006), but also affects the timing and magnitude of particulate and dissolved material exported from terrestrial catchments to the sea.

The larger Arctic rivers have lake-rich floodplains that are productive sites for aquatic and semi-aquatic plants and animals. These also act as biogeochemical processing regions for river water before its discharge to the sea (e.g., Emmerton et al. 2008), and changes in the flooding regime are likely to affect not only the ecology of the floodplain delta, but also biogeochemical characteristics, primary production, and food web processes in coastal marine ecosystems. Ice-jams result in high spring flood levels, and decreasing ice compounded with reduced spring runoff as a result of less winter snow pack will reduce ice-jam flooding (Prowse et al. 2011a; and references therein). Changes in coastal stamukhi ice will also affect how river water is biogeochemically modified before it is discharged into the marine environment (Fig. 1).

\section{Sea Ice}

Sea ice is a habitat for marine mammals such as polar bears and walruses (Fig. 7), and for diverse communities of other biota that live within or in association with the ice. Changes have already been observed in Arctic marine ecosystems that have been attributed to recent decreases in sea-ice extent and duration. These include: a regime shift in the Bering Sea from an ice-dominated ecosystem with bottom-feeding birds and mammals that depend on carbon input to the benthos from sea-ice algae, to an open water ecosystem more dominated by plankton and pelagic fish (Grebmeier et al. 2006); satellite evidence of increased phytoplankton biomass in response to more open water and a longer open-water season (Arrigo et al. 2008); and a decline in condition and reproductive success of polar bears in western Hudson Bay associated with earlier ice breakup (Regehr et al. 2007). Changes in sea ice are likely to continue throughout this century, and Arctic seas may be seasonally ice-free within a few decades (Meier et al. 2011).

Changing sea-ice conditions (less multi-year ice, more seasonal ice, earlier melt, later freeze-up) may lead to increased light availability for photosynthesis and therefore increased biological productivity at all trophic levels, particularly in the marginal ice zone. However, these positive effects may be offset by increased freshwater runoff and ice melting that enhances stratification and inhibits the entrainment of nutrients from the deeper layers into the surface waters by mixing, thereby limiting phytoplankton production. Field measurements in the Canada Basin have revealed high $p \mathrm{CO}_{2}$ levels in its surface waters after extensive ice melt had occurred, leading to the prediction that the Arctic Ocean will not become a large photosynthetic sink for atmospheric $\mathrm{CO}_{2}$ under ice-free conditions (Cai et al. 2010). Also, increased runoff of river water rich in dissolved and particulate organic matter may cause local reductions in underwater light, particularly for the deep population maxima of phytoplankton that can contribute a large fraction of total water-column photosynthesis in the Arctic Ocean (Martin et al. 2010). The loss of snow-covered sea ice also results in water column biota experiencing much greater ultraviolet (UV) radiation exposure, and this high energy waveband may have negative effects on some phytoplankton and other biota (details in Vincent et al. 2011).

Sea ice is an important feeding habitat for lipid-rich, Arctic-adapted zooplankton, which graze on ice algae and ice edge phytoplankton blooms. These zooplankton populations in turn provide high quality food for seabirds, fish, and marine mammals. The algal populations in these habitats also provide an important food source to benthic 


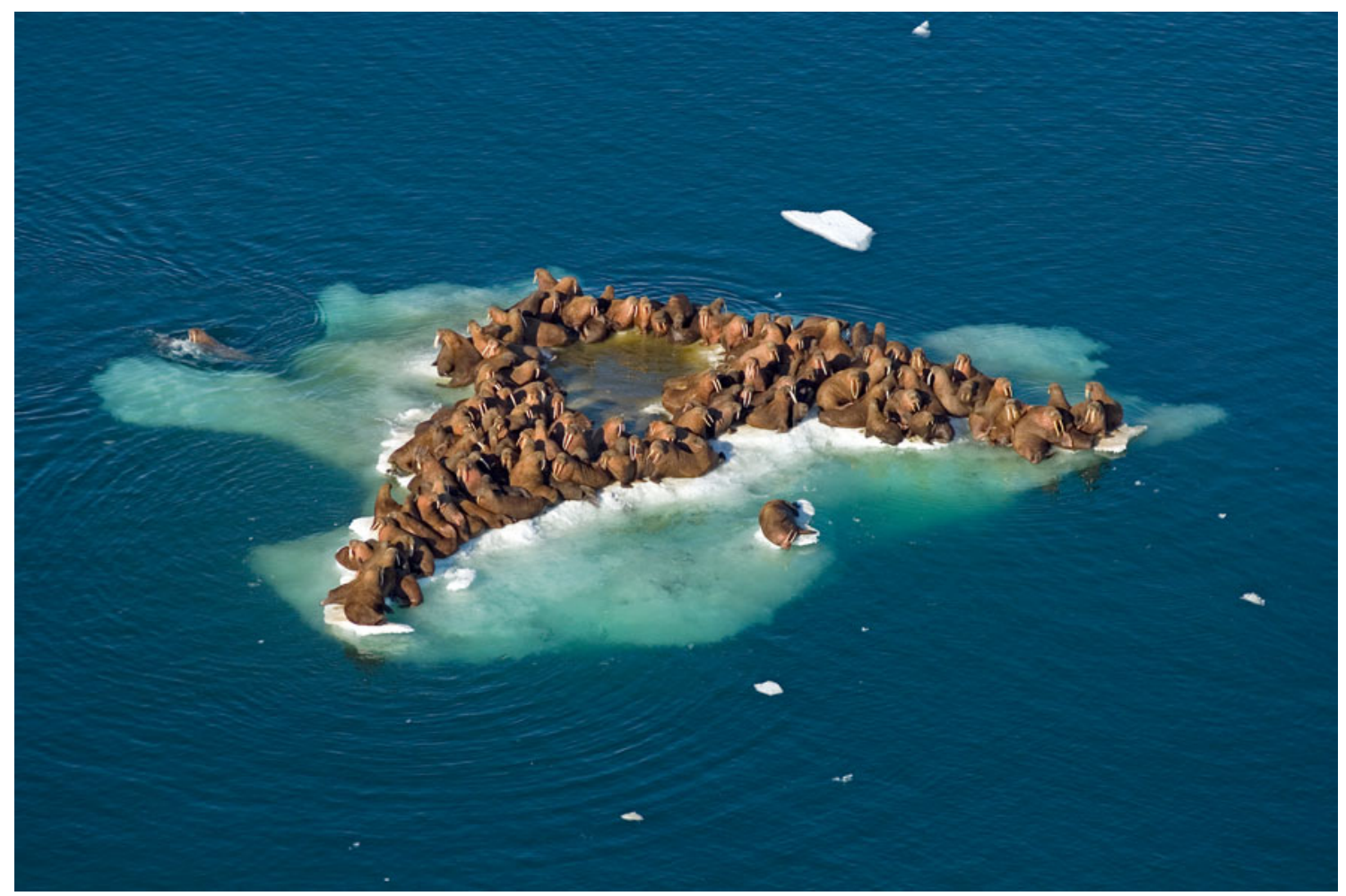

Fig. 7 Sea ice ecosystems in decline. Walruses use sea ice as a haul out platform over foraging areas, and substantial declines in their populations are predicted in response to sea-ice reduction (Jay et al. 2011). Photocredit: Steven J. Kazlowski/ArcticNet

communities. Changing sea-ice conditions therefore have wide ranging impacts on Arctic marine food webs, including direct and indirect effects on ice-associated marine mammals (details in Kovacs et al. 2011). Whale species may differ greatly in their sensitivity to ice change depending on their degree of specialization and flexibility in diet. Narwhals are likely to be strongly impacted by the loss of pack ice in their winter-time benthic feeding regions, while the more generalist feeding habits of beluga and bowhead whales may allow them to adjust more readily to changes in the Arctic marine ecosystem caused by loss of sea ice. Gray whales and other migratory species are likely to expand their ranges and periods of residency in the Arctic. Polar bears are especially prone to negative consequences of the changing sea-ice conditions (Fig. 8), and drastic declines have been predicted (e.g., Durner et al. 2009), including complete extirpation from many areas where they are presently common (Regehr et al. 2010). The ecology of terrestrial species that use sea ice seasonally as a foraging habitat (e.g., Arctic fox, Tarroux et al. 2010) will also be strongly modified by sea-ice decline.

Ice-associated zooplankton are important for certain fish species, notably capelin and Arctic cod, which in turn are resources for several commercially important species such as Atlantic cod, as well as whales (e.g., beluga). Bird populations that depend on these zooplankton, such as some auklets, are likely to experience ongoing decline, however some bird species appear to be increasing in population size, possibly as a result of earlier ice breakup (details in Kovacs et al. 2011).

Reduced sea ice is also almost certain to lead to increased shipping, tourism and exploration for oil, gas and mineral resources (details in Hovelsrud et al. 2011), all of which are likely to have ecological impacts on land as well as in the sea. Changes in sea ice have begun to affect hunting and traditional over-ice transport routes, which are becoming increasingly dangerous, even in winter. Finally, the increased extent and duration of open water will affect the temperature and precipitation regimes of coastal landbased ecosystems, and will result in faster rates of coastal erosion, in turn affecting habitats at the land-ocean margin.

\section{PERMAFROST}

Permafrost, defined as soil, rock or sediment that remains at or below $0^{\circ} \mathrm{C}$ for two or more consecutive years, covers vast areas of the Arctic. Unlike sea ice, it does not provide a unique habitat for a dependent biota (with the exception perhaps of extreme cold-adapted microbes in permafrost micro-niches; Gilichinsky et al. 2008), but it does strongly influence the hydrology, biogeochemistry, and geomorphology of the 
Fig. 8 Declining polar bear habitats. Continental shelf waters partially covered by sea ice provide the optimal habitat for polar bears and the seals they prey upon. Large declines are predicted over the twentyfirst century, with considerable variation among different sectors of the Arctic Ocean (Durner et al. 2009). Photocredit: Thorsten Mauritsen/ArcticNet

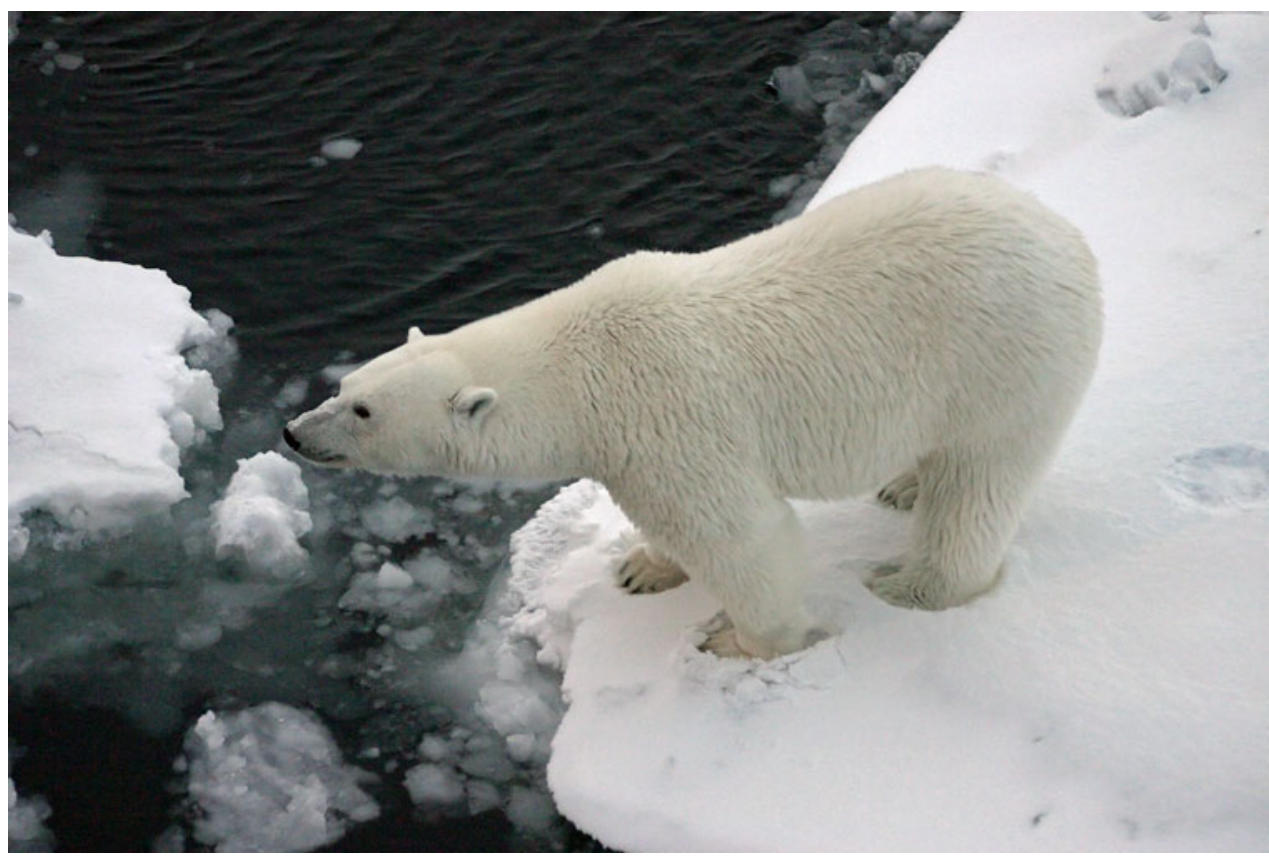

landscape and thereby the biological productivity and biodiversity of northern regions. Permafrost provides an impermeable barrier that prevents drainage, and the resultant high water table favors wetlands, lakes, and ponds, and their associated biota (Woo and Young 1998). Qualitatively different responses are being observed to the erosion of permafrost soils, including creation of lakes and wetlands, conversion of forests to fens, and increased drainage with loss of lakes or little change in vegetation (Jorgenson and Osterkamp 2005).

In many parts of the Arctic, the permafrost has begun to warm and the active layer has deepened (details in Callaghan 2011e). However, the extent of these changes is highly variable regionally; a deepening of the active layer by several meters (or more) has been documented at some sites while there is no detectable change at other sites. Slumping and drainage due to permafrost melting can damage some vegetation, such as forest ecosystems, but the disturbance also allows new species to colonize and become established, including invasive species from the south. In parts of the Arctic, thermokarst lakes and wetlands are expanding as a result of permafrost thawing and erosion (Fig. 4), thereby producing more habitats for aquatic birds and other animals. In subarctic Québec the southern limit of discontinuous permafrost has moved $130 \mathrm{~km}$ northward over the past few decades (Thibault and Payette 2009). In some other areas, however, the degradation of permafrost is causing a draining of the landscape and loss of aquatic and semi-aquatic ecosystems. The latter changes could result in a more homogeneous northern landscape, with reduced habitat and species diversity (e.g., in Fennoscandia, Luoto et al. 2004).
There are complex interactions between permafrost soils and vegetation that affect soil temperature, surface albedo and even a region's sensitivity to fire. By trapping snow and directly insulating the ground with its foliage, plant communities can reduce soil temperatures by several degrees, and permafrost patches may therefore continue to exist beneath undisturbed vegetation despite rising air temperatures. Trees and shrubs have a much lower albedo than snow on tundra, and their expansion over northern landscapes (Tape et al. 2006) is likely to cause increased heating; after snowmelt, however, increased evapotranspiration from vegetation can also cause local cooling (Göttel et al. 2008). Finally, increased vegetation biomass combined with drier conditions is likely to increase the frequency of fires on the tundra, with additional impacts on permafrost stability and temperature.

Thawing permafrost may release organic matter, gases, inorganic solutes, and microbiota into the surrounding environment, with implications not only for land-based ecosystems, but also for thaw ponds, northern rivers and the coastal ocean. The increasing incidence of fires and other extreme weather events (Post et al. 2009) may also exacerbate permafrost degradation and the transfer of soil materials into waterways. Terrigenous, organic-rich particles released into rivers are a substrate for Bacteria and Archaea, and climate effects on these organisms combined with increased light limitation of phytoplankton may drive Arctic rivers and estuaries toward even greater heterotrophy and net $\mathrm{CO}_{2}$ efflux in the future (Vallières et al. 2008). Viable microbial populations dating back three million years have been identified in Siberian permafrost (Gilichinsky et al. 2008), and the impacts of release of 
these ancient genotypes into the present-day biosphere are completely unknown. Globally significant quantities of organic carbon are stored in frozen northern soils (Tarnocai et al. 2009), and some of these compounds released into lakes, rivers and coastal seas may be converted into $\mathrm{CO}_{2}$ and methane (Walter et al. 2006 and references therein). Subarctic thaw lakes have been found to be stratified throughout most of the year, with anoxic bottom waters despite their shallow depths. These conditions favor microbial processes that convert allochthonous tundra carbon to methane, which is ultimately released to the atmosphere (Laurion et al. 2010). Large quantities of methane are stored in the tundra and in the frozen sediments beneath Arctic seas as gas hydrates and free gas. The continuous efflux of this gas (e.g., into the ocean over the East Siberian Arctic Shelf; Shakhova et al. 2010) is likely to stimulate methanotrophic bacteria and perhaps chemotrophic food webs, but such effects have not been evaluated, and there is large uncertainty about how much warming would be required to trigger globally significant releases from these vast greenhouse gas reservoirs.

\section{CONCLUSIONS}

The Arctic's changing climate has already had marked impacts on snow, water, ice, and permafrost regimes of the region, and such changes will continue to accelerate in the future. In each ecosystem type, from permafrost to sea ice, there are large variations among Arctic sectors in the pace of change. This heterogeneity is likely to persist in the future, underscoring the urgent need for improved spatial coverage of data collection, and for downscaling climate projections and impact assessments to the regional level.

Extreme climate events are likely to continue to have severe effects on many ecosystem types. Examples discussed above include rain on snow giving rise to crusts of ice that impede animal feeding, episodes of warming and melting of snow that break winter dormancy and coldtolerance of plants and animals, and winter breakup of river ice that disrupts fish habitats. Such extremes compounded with the general warming trend is hastening the demise of unique habitats, for example palsa mires in Fennoscandia, ice shelves and epishelf lakes in northern Canada, and multiyear sea ice across the Arctic Ocean.

As the Arctic region warms and loses its extreme habitats, it is becoming more homogenous and more suited to generalist species. Specialists such as psychrophilic microbes, polar desert plants, and obligate sea-ice biota including narwhals, walruses, and polar bears will become increasingly limited in habitat range, and invasive generalists from the south are likely to become increasingly prevalent constituents of each type of Arctic ecosystem.
Local biodiversity may thereby increase in terms of species richness, while Arctic endemic species decline. The loss of perennial sea ice and increased access to resources in the Arctic will be accompanied by increased human activities, which will have effects on all ecosystems. Accelerated development of the North will create ongoing challenges for Arctic ecosystem management, and for northern communities that depend on these ecosystems.

Acknowledgments We thank the SWIPA editorial team for their advice and input, Marie-Josée Maltais and Mickaël Lemay for assistance with manuscript preparation; NSERC, ArcticNet and the Canada Research Chair program for support to WFV; and ArcticNet for the provision of photographs.

\section{REFERENCES}

Arrigo, K.R., G. van Dijken, and S. Pabi. 2008. Impact of a shrinking Arctic ice cover on marine primary production. Geophysical Research Letters 35: L19603. doi:10.1029/2008GL035028.

Breen, K., and E. Lévesque. 2006. Proglacial succession of biological soil crusts and vascular plants: Biotic interactions in the High Arctic. Canadian Journal of Botany 84: 1714-1731.

Brown, R.D., and P. Mote. 2009. The response of Northern Hemisphere snow cover to a changing climate. Journal of Climate 22: 2124-2145.

Cai, W.-J., L. Chen, B. Chen, Z. Gao, S.H. Lee, J. Chen, D. Pierrot, K. Sullivan, et al. 2010. Decrease in the $\mathrm{CO}_{2}$ uptake capacity in an ice-free Arctic Ocean basin. Science 329: 556-559.

Callaghan, T. V., M. Johansson, J. Key, T. Prowse, M. Ananicheva, and A. Klepikov. 2011a. Chapter 11.1: Synthesis of feedbacks and interactions: From the cryosphere to the climate systemEffects over various spatial and temporal scales. In Snow, Water, Ice and Permafrost in the Arctic (SWIPA), Arctic Monitoring and Assessment Programme (AMAP), Oslo.

Callaghan, T.V., M. Johansson, J. Key, T. Prowse, M. Ananicheva, and A. Klepikov. 2011b. Feedbacks and interactions: From the arctic cryosphere to the climate system. In Arctic cryosphereChanges and impacts, ed. T.V. Callaghan, M. Johansson, and T.D. Prowse. Ambio 40(S1). doi:10.1007/s13280-011-0215-8

Callaghan, T.V., M. Johansson, R.D. Brown, P.Ya. Groisman, N. Labba, and V. Radionov. 2011c. Chapter 4: Changing snow cover and its impacts. In Snow, Water, Ice and Permafrost in the Arctic (SWIPA), Arctic Monitoring and Assessment Programme (AMAP), Oslo.

Callaghan, T.V., M. Johansson, R.D. Brown, P. Ya. Groisman, N. Labba, V. Radionov, R.G. Barry, O.N. Bulygina, et al. 2011d. The changing face of Arctic snow cover: A synthesis of observed and projected changes. In Arctic cryosphere-Changes and impacts, ed. T.V. Callaghan, M. Johansson, and T.D. Prowse. Ambio 40(S1). doi:10.1007/s13280-011-0212-y.

Callaghan, T.V., M. Johansson, O. Anisimov, H.H. Christiansen, A. Instanes, V. Romanovsky, and S. Smith, 2011e. Chapter 5: Changing permafrost and its impacts. In Snow, Water, Ice and Permafrost in the Arctic (SWIPA), Arctic Monitoring and Assessment Programme (AMAP), Oslo.

Carrie, J., F. Wang, H. Sanel, R.W. Macdonald, P.M. Outridge, and G.A. Stern. 2010. Increasing contaminant burdens in an Arctic fish, Burbot (Lota lota), in a warming climate. Environmental Science and Technology 44: 316-322.

Dahl-Jensen, D., J.J. Bamber, C.E. Bøggild, E. Buch, J.H. Hesselbjerg Christensen, K. Dethloff, M. Fahnestock, et al. 2011. Chapter 8: 
The Greenland Ice Sheet in a changing climate. In Snow, Water, Ice and Permafrost in the Arctic (SWIPA), Arctic Monitoring and Assessment Programme (AMAP), Oslo.

Durner, G.M., D.C. Douglas, R.M. Nielson, S.C. Amstrup, T.L. McDonald, I. Stirling, M. Mauritzen, E.W. Born, et al. 2009. Predicting 21st-century polar bear habitat distribution from global climate models. Ecological Monographs 179: 25-58.

Emmerton, C. A., L.F.W. Lesack, and W.F. Vincent. 2008. Mackenzie River nutrient delivery to the Arctic Ocean and effects of the Mackenzie Delta during open water conditions. Global Biogeochemical Cycles 22: GB1024, doi:10.1029/2006GB002856.

Fleming, S.W. 2005. Comparative analysis of glacial and nival stream flow regimes with implications for lotic habitat quantity and fish species richness. River Research and Applications 21: 363-379.

Forchhammer, M.C., N.M. Schmidt, T.T. Høye, T.B. Berg, D.K. Hendrichsen, and E. Post. 2008. Population dynamical responses to climate change. Advances in Ecological Research 40: $391-420$

Fortier, L., D. Barber, and J. Michaud. 2008. On thin ice: A synthesis of the Canadian Arctic Shelf Exchange Study (CASES). Winnipeg, MB: Aboriginal Issue Press, University of Manitoba.

Galand, P.E., C. Lovejoy, J. Pouliot, M.-E. Garneau, and W.F. Vincent. 2008. Microbial community diversity and heterotrophic production in a coastal Arctic ecosystem: A stamukhi lake and its source waters. Limnology and Oceanography 53: 813-823.

Gilichinsky, D., T. Vishnivetskaya, M. Petrova, E. Spirina, V. Mamykin, and E. Rivkina. 2008. Bacteria in permafrost. In Psychrophiles: from biodiversity to biotechnology, ed. R. Margesin, F.S., J.-C. Marx, and C. Gerday. Berlin: Springer.

Göttel, H., J. Alexander, E. Keup-Thiel, D. Rechid, S. Hagemann, T. Blome, A. Wolf, and D. Jacob. 2008. Influence of changed vegetation fields on regional climate simulations in the Barents Sea region. Climatic Change 87: 35-50

Grebmeier, J.M., J.E. Overland, S.E. Moore, E.V. Farley, E.C. Carmack, L.W. Cooper, K.E. Frey, J.H. Helle et al. 2006. A major ecosystem shift in the northern Bering Sea. Science 311: 1461-1461.

Hodgson, D.A., and J.P. Smol. 2008. High latitude paleolimnology. In Polar lakes and rivers-Limnology of Arctic and Antarctic aquatic ecosystems, ed. W.F. Vincent, and J. Laybourn-Parry, 43-64. Oxford: Oxford University Press.

Hovelsrud, G.K., B. Poppel, B. van Oort, J.D. Reist, D. Armitage, H. Dannevig, H. Huntington, A.L. Lovecraft, et al. 2011. Chapter 10: Arctic societies, cultures, and peoples in a changing cryosphere. In Snow, Water, Ice and Permafrost in the Arctic (SWIPA), Arctic Monitoring and Assessment Programme (AMAP), Oslo.

Huusko, A., L. Greenberg, M. Stickler, T. Linnansaari, M. Nykänen, T. Vehanen, S. Koljonen, P. Louhi, and K. Alfredsen. 2007. Life in the ice lane: The winter ecology of stream salmonids. River Research and Applications 23: 469-491.

Jay, C.V., B.G. Marcot, and D.C. Douglas. 2011. Projected status of the Pacific walrus (Odobenus rosmarus divergens) in the twentyfirst century. Polar Biology 34: 1065-1084.

Jorgenson, M.T., and T.E. Osterkamp. 2005. Response of boreal ecosystems to varying modes of permafrost degradation. Canadian Journal of Forest Research 35: 2100-2111.

Kausrud, K.L., A. Mysterud, H. Steen, J.O. Vik, E. Østbye, B. Cazelles, E. Framstad, A.M. Eikeset, et al. 2008. Linking climate change to lemming cycles. Nature 456: 93-97.

Kovacs, K.M., C. Michel, B. Bluhm, T. Gaston, R. Gradinger, G. Hunt, S.E. Moore, P. Renaud, and S. Rysgaard. 2011. Chapter 3: Biological impacts of changes to sea ice in the Arctic. In Snow, Water, Ice and Permafrost in the Arctic (SWIPA), Arctic Monitoring and Assessment Programme (AMAP), Oslo.
Laurion, I., W.F. Vincent, L. Retamal, C. Dupont, P. Francus, S. MacIntyre, and R. Pienitz. 2010. Variability in greenhouse gas emissions from permafrost thaw ponds. Limnology and Oceanography 55: 115-133.

Lesack, L.F.W., and P. Marsh. 2007. Lengthening plus shortening of river-to-lake connection times in the Mackenzie River Delta respectively via two global change mechanisms along the Arctic coast. Geophysical Research Letters 34: 1-6. (L23404).

Li, W.K.W., F.A. McLaughlin, C. Lovejoy, and E.C. Carmack. 2009. Smallest algae thrive as the Arctic Ocean freshens. Science 326: 539.

Luoto, M., R.K. Heikkinen, and T.R. Carter. 2004. Loss of palsa mires in Europe and biological consequences. Environmental Conservation 31: 1-8.

Madsen, J., M. Tamstorf, M. Klaassen, N. Eide, C. Glahder, F. Rigét, H. Nyegaard, and F. Cottaar. 2007. Effects of snow cover on the timing and success of reproduction in high-Arctic pink-footed geese Anser brachyrhynchus. Polar Biology 30: 1363-1372.

Martin, J., J.-E. Tremblay, J. Gagnon, G. Tremblay, A. Lapoussière, C. Jose, M. Poulin, M. Gosselin, et al. 2010. Prevalence, structure and properties of subsurface chlorophyll maxima in Canadian Arctic waters. Marine Ecology Progress Series 412: 69-84.

Mech, L.D. 2004. Is climate affecting wolf populations in the high Arctic? Climatic Change 67: 87-93.

Meier, W.N., S. Gerland, M.A. Granskog, J.R. Key, C. Haas, G.K. Hovelsrud, K. Kovacs, A. Makshtas, C. Michel, D. Perovich, J.D. Reist, and B.E.H. van Oort. 2011. Chapter 9: Sea ice. In Snow, Water, Ice and Permafrost in the Arctic (SWIPA), Arctic Monitoring and Assessment Programme (AMAP), Oslo.

Miller, F.L., and S.J. Barry. 2009. Long-term control of Peary caribou numbers by unpredictable, exceptionally severe snow or ice conditions in a non-equilibrium grazing system. Arctic 62: 175-189.

Milner, A.M., A.E. Robertson, K. Monaghan, A.J. Veal, and E.A. Flory. 2008. Colonization and development of a stream community over 28 years; Wolf Point Creek in Glacier Bay, Alaska. Frontiers in Ecology and the Environment 6: 413-419.

Post, E., M.C. Forchhammer, M.S. Bret-Harte, T.V. Callaghan, T.R. Christensen, B. Elberling, A.D. Fox, O. Gilg, et al. 2009. Ecological dynamics across the Arctic associated with recent climate change. Science 325: 1355-1358.

Power, M., J.D. Reist, and J.B. Dempson. 2008. Fish in high-latitude lakes. In Polar lakes and rivers-Limnology of Arctic and Antarctic aquatic ecosystems, ed. W.F. Vincent, and J. Laybourn-Parry. Oxford: Oxford University Press.

Prowse, T., K. Alfredsen, S. Beltaos, B. Bonsal, C. Duguay, A. Korhola, J. McNamara, W.F. Vincent, V. Vuglinsky, and G. Weyhenmeyer. 2011a. Chapter 6: Changing lake and river ice regimes: Trends, effects and implications. In Snow, Water, Ice and Permafrost in the Arctic (SWIPA), Arctic Monitoring and Assessment Programme (AMAP), Oslo.

Prowse, T., K. Alfredsen, S. Beltaos, B. Bonsal, C. Duguay, A. Korhola, J. McNamara, R. Pienitz, W.F. Vincent, V. Vuglinsky, and G.A. Weyhenmeyer. 2011b. Past and future changes in Arctic lake and river ice. In Arctic cryosphere-Changes and impacts, ed. T.V. Callaghan, M. Johansson, and T.D. Prowse. Ambio 40(S1). doi:10.1007/s13280-011-0216-7.

Prowse, T.D., C. Furgal, H. Melling, and S.L. Smith. 2009. Implications of climate change for northern Canada: The physical environment. Ambio 38: 266-271.

Prowse, T.D., F.J. Wrona, J.D. Reist, J.J. Gibson, J.E. Hobbie, L.M.J. Lévesque, and W.F. Vincent. 2006. Climate change effects on hydroecology of arctic freshwater ecosystems. Ambio 35: 347-358.

Rautio, M., F. Dufresne, I. Laurion, S. Bonilla, W.F. Vincent, and K. Christoffersen, 2011. Shallow freshwater ecosystems of the circumpolar Arctic. Ecoscience 18: 204-222. 
Regehr, E.V., C.M. Hunter, H. Caswell, S.C. Amstrup, and I. Stirling. 2010. Survival and breeding of polar bears in the southern Beaufort Sea in relation to sea ice. Journal of Animal Ecology 79: 117-127.

Regehr, E.V., N.J. Lunn, S.C. Amstrup, and I. Stirling. 2007. Effects of earlier sea ice breakup on survival and population size of polar bears in western Hudson Bay. Journal of Wildlife Management 71: 2673-2683.

Rennert, K., G. Roe, J. Putkonen, and C. Bitz. 2009. Soil thermal and ecological impacts of rain on snow events in the circumpolar Arctic. Journal of Climate 22: 2302-2315.

Semkin, R.G., G. Mierle, and R.J. Neureuther. 2005. Hydrochemistry and mercury cycling in a High Arctic watershed. Science of the Total Environment 342: 199-221.

Shakhova, N., I. Semiletov, A. Salyuk, V. Yusupov, D. Kosmach, and O. Gustafsson. 2010. Extensive methane venting to the atmosphere from sediments of the east Siberian Arctic Shelf. Science 327: 1246-1250.

Sharma, S., D.A. Jackson, C.K. Minns, and B.J. Shuter. 2007. Will northern fish populations be in hot water because of climate change? Global Change Biology 13: 2052-2064.

Sharp, M., M. Ananicheva, A. Arendt, J.-O. Hagen, R. Hock, E. Joseberger, R.D. Moore, W.T. Pfeffer, and G.J. Wolken. 2011. Chapter 7: Mountain glaciers and ice caps. In Snow, Water, Ice and Permafrost in the Arctic (SWIPA), Arctic Monitoring and Assessment Programme (AMAP), Oslo.

Shiklomanov, A.I., and R.B. Lammers. 2009. Record Russian river discharge in 2007 and the limits of analysis. Environmental Research Letters 4: 045015. doi:10.1088/1748-9326/4/4/045015.

Smith, L.C., Y. Sheng, G.M. MacDonald, and L.D. Hinzman. 2005. Disappearing Arctic lakes. Science 308: 1429.

Smol, J.P., and M.S.V. Douglas. 2007. Crossing the final ecological threshold in high Arctic ponds. Proceedings of the National Academy of Sciences USA 104: 12395-12397.

Tape, K., M. Sturm, and C. Racine. 2006. The evidence for shrub expansion in Northern Alaska and the Pan-Arctic. Global Change Biology 12: 686-702.

Tarnocai, C., J.G. Canadell, E.A.G. Schuur, P. Kuhry, G. Mazhitova, and S. Zimov. 2009. Soil organic carbon pools in circumpolar permafrost region. Global Biogeochemical Cycles 23:GB2023, doi:10.1029/2008GB003327.

Tarroux, A., D. Berteaux, and J. Bêty. 2010. Northern nomads: Ability for extensive movements in adult Arctic foxes. Polar Biology 33: 1021-1026.

Thibault, S., and S. Payette. 2009. Recent permafrost degradation in bogs of the James Bay area, Northern Quebec, Canada. Permafrost and Periglacial Processes 20: 383-389.

Turunen, M., P. Soppela, H. Kinnunen, M.L. Sutinen, and F. Martz. 2009. Does climate change influence the availability and quality of reindeer forage plants? Polar Biology 6: 813-832.

Vallières, C., L. Retamal, C. Osburn, and W.F. Vincent. 2008. Bacterial production and microbial food web structure in a large Arctic river and the coastal Arctic Ocean. Journal of Marine Systems 74: 756-773.

Veillette, J., D.R. Mueller, D. Antoniades, and W.F. Vincent. 2008. Arctic epishelf lakes as sentinel ecosystems: Past, present and future. Journal of Geophysical Research-Biogeosciences 113: G04014. doi:10.1029/2008JG000730.

Vincent, W.F. 2000. Cyanobacterial dominance in the polar regions. In. Ecology of the cyanobacteria: Their diversity in space and time, ed B. Whitton and M. Potts. Dordrecht: Kluwers Academic Press.

Vincent, W.F., and C. Belzile. 2003. Biological UV exposure in the polar oceans: Arctic-Antarctic comparisons. In Antarctic biology in a global context, ed. A.H.L. Huiskes, W.W.C. Gieskes, J. Rozema, R.M.L. Schorno, S.M. van der Vies and W.J. Wolff, 176-181. Leiden: Backhuys Publishers.
Vincent, W.F. 2010. Microbial ecosystem responses to rapid climate change in the Arctic. The ISME Journal 4: 1089-1091.

Vincent, W.F., T.V. Callaghan, D. Dahl-Jensen, M. Johansson, K.M. Kovacs, C. Michel, T. Prowse, J.D. Reist, and M. Sharp. 2011. Chapter 11: Effects of climate change on snow, water, ice, and permafrost in Arctic ecosystems-Synthesis. In Snow, Water, Ice and Permafrost in the Arctic (SWIPA), Arctic Monitoring and Assessment Programme (AMAP), Oslo.

Vincent, W.F., L.G. Whyte, C. Lovejoy, C.W. Greer, I. Laurion, C.A. Suttle, J. Corbeil, and D.R. Mueller. 2009. Arctic microbial ecosystems and impacts of extreme warming during the International Polar Year. Polar Science 3: 171-180.

Vors, L.S., and M.S. Boyce. 2009. Global declines of caribou and reindeer. Global Change Biology 15: 2626-2633.

Walsh, J.E., J.E. Overland, P.Y. Groisman, and B. Rudolf. 2011a. Chapter 2: Arctic climate: Recent variations. In Snow, Water, Ice and Permafrost in the Arctic (SWIPA), Arctic Monitoring and Assessment Programme (AMAP), Oslo.

Walsh, J.E., J.E. Overland, P.Y. Groisman, and B. Rudolf, 2011b. Ongoing climate change in the Arctic. In Arctic cryosphereChanges and impacts, ed. T.V. Callaghan, M. Johansson, and T.D. Prowse. Ambio 40(S1). doi:10.1007/s13280-011-0211-z.

Walter, K.M., S.A. Zimov, J.P. Chanton, D. Verbyla, and F.S. Chapin III. 2006. Methane bubbling from Siberian thaw lakes as a positive feedback to climate warming. Nature 443: 71-75.

Wilmking, M., R. D’Arrigo, G.C. Jacoby, and G.P. Juday. 2005. Increased temperature sensitivity and divergent growth trends in circumpolar boreal forests. Geophysical Research Letters 32: L15715. doi:10.1029/2005GL023331.

Woo, M.K., and K.L. Young. 1998. Characteristics of patchy wetlands in a polar desert environment, Arctic Canada. In Proceedings of Seventh International Conference on Permafrost, ed. A.G. Lewkowicz, and M. Allard. Yellowknife, Canada. June 1998. Collection Nordicana 57: 1141-1146.

Woo, M.K., and K.L. Young. 2003. Hydrogeomorphology of patchy wetlands in the High Arctic, polar desert environment. Wetlands 23: 291-309.

\section{AUTHOR BIOGRAPHIES}

Warwick F. Vincent $(\square)$ is a Professor of biology and Canada Research Chair at Laval University, Canada, where he is also director of the Centre for Northern Studies (CEN), and member of the Takuvik Joint International Laboratory, Université Laval (Canada)-CNRS (France). He works on the effects of environmental change on polar aquatic ecosystems.

Address: Département de Biologie \& Centre d'Études Nordiques (CEN), Laval University, Québec City, QC G1V 0A6, Canada.

e-mail: warwick.vincent@bio.ulaval.ca

Terry V. Callaghan is a Distinguished Research Professor at the Royal Swedish Academy of Sciences and Professor of Arctic Ecology at Universities of Sheffield, UK and Lund, Sweden. He specializes in Arctic ecology, and climate and UV-B radiation impacts on Arctic ecosystems.

Address: Royal Swedish Academy of Sciences, 10405 Stockholm, Sweden.

e-mail: terry_callaghan@btinternet.com

Dorthe Dahl-Jensen is a professor at the University of Copenhagen, working on ice core records of climate, and the history and evolution of the Greenland Ice Sheet.

Address: Niels Bohr Institutet, University of Copenhagen, 2100 Copenhagen, Denmark.

e-mail: ddj@gfy.ku.dk 
Margareta Johansson is a researcher at the Department of Earth and Ecosystem Sciences, Lund University and at the Royal Swedish Academy of Sciences, Stockholm, Sweden. She specializes in permafrost dynamics in relation to climate change and its impact on ecosystems.

Address: Department of Earth and Ecosystem Sciences, Division of Physical Geography and Ecosystem Analyses, Lund University, Sölvegatan 12, 22362 Lund, Sweden.

e-mail: margareta.johansson@nateko.lu.se

Kit M. Kovacs leads the biodiversity research program at the Norwegian Polar Institute, and works on marine mammal population biology, ecology and management.

Address: Norwegian Polar Institute, 9296 Troms $\varnothing$, Norway.

e-mail: kit@npolar.no

Christine Michel is a research scientist at Fisheries and Oceans Canada. Her research focuses on the role of sea ice in Arctic marine ecosystems.

Address: Fisheries and Oceans Canada, 501 University Crescent, Winnipeg, MB R3T 2N6, Canada.

e-mail: christine.michel@dfo-mpo.gc.ca
Terry Prowse is a senior Research Scientist with Environment Canada and a Professor in the Department of Geography at the University of Victoria. His research focuses on the effects of climate variability and change on cold-regions hydrology, hydro-climatology, and hydro-ecology.

Address: Environment Canada, Department of Geography, University of Victoria, Victoria, BC V8P 5C2, Canada.

e-mail: terry.prowse@ec.gc.ca

James D. Reist is a research scientist at Fisheries and Oceans Canada and works on northern fish ecology.

Address: Fisheries and Oceans Canada, 501 University Crescent, Winnipeg, MB R3T 2N6, Canada.

e-mail: jim.reist@dfo-mpo.gc.ca

Martin Sharp is chair of Earth and Atmospheric Sciences at the University of Alberta, where he is professor of glaciology working on polar ice caps and glaciers.

Address: Earth and Atmospheric Sciences, University of Alberta, Edmonton, AB T6G 2E3, Canada.

e-mail: martin.sharp@ualberta.ca 